\title{
Research Article: Suitability of alternate cytoplasm based hybrids for summer adaptation in pearl millet [Pennisetum glaucum (L.). R. Br.]
}

\section{P. SANJANA REDDY AND R.S. MEENA}

Article Chronicle: Received :

19.07.2017;

Accepted :

03.08.2017

KEY WoRds:

Pearl millet, $\mathrm{A}_{4}$ cytoplasm, Hybrid, Summer, Panicle, Harvest index length, panicle weight and panicle harvest index.
SUMMARY : Pearl millet occupies a prominent place after rice and wheat in India. It is predominantly grown in rainy season with significant increase in area under summer grown pearl millet. The hybrids grown during summer have poor seed set though a few hybrids with good seed production potential are reported. A study was taken upto compare the A1 CMS system $\left(97111 \mathrm{~A}_{1}\right.$ and $\left.98222 \mathrm{~A}_{1}\right)$ with A4 CMS $\left(99222 \mathrm{~A}_{4}\right)$ and between high yielding $(97111)$ and drought tolerant $(98222,99222)$ backgrounds. Of the 66 hybrids evaluated, the hybrid $97111 \mathrm{~A} \times \mathrm{R} 42$ was the best performing with a grain yield of 6.27 t/ha. The hybrids based on 97111A performed better for plant height and panicle emergence while those based on 98222A were early to flower, had more number of tillers, had greater panicle width and panicle weight. The hybrids based on $\mathrm{A}_{4} \mathrm{CMS}$ based female parent $98222 \mathrm{~A}$ had more panicle length, grain yield and panicle harvest index. it has been observed from the current study that the $\mathrm{A}_{4}$ cytoplasm based hybrids in drought tolerant genetic background perform well as compared to $\mathrm{A}_{1} \mathrm{CMS}$ based hybrids. For summer adaptation, the grain yield was positively associated with plant height, panicle

How to cite this article : Reddy, P. Sanjana and Meena, R.S. (2017). Suitability of alternate cytoplasm based hybrids for summer adaptation in pearl millet [Pennisetum glaucum (L). R. Br.]. Agric. Update, 12(TECHSEAR7) : 1904-1908; DOI: 10.15740/HAS/AU/12.TECHSEAR(7)2017/1904-1908.
Author for correspondence :

\section{P. SANJANA REDDY}

Indian Institute of Millets Research, Rajendranagar, HYDERABAD (TELANGANA) INDIA

See end of the article for authors' affiliations 